\title{
Cross-cultural adaptation and reliability testing of the Tilburg Frailty Indicator for optimizing care of Polish patients with frailty syndrome
}

This article was published in the following Dove Press journal:

Clinical Interventions in Aging

25 June 2014

Number of times this article has been viewed

\author{
Izabella Uchmanowicz' \\ Beata Jankowska-Polańska' \\ Maria Łoboz-Rudnicka² \\ Stanisław Manulik ${ }^{3}$ \\ Krystyna Łoboz-Grudzień ${ }^{1,2}$ \\ Robbert JJ Gobbens ${ }^{4}$ \\ 'Department of Clinical Nursing, \\ Wrocław Medical University, \\ 2Department of Cardiology, \\ T Marciniak Memorial Hospital, \\ ${ }^{3}$ Primary Care Practice, Wrocław, \\ Poland; ${ }^{4}$ Research and Development \\ Center Innovations in Care, \\ Rotterdam University of Applied \\ Sciences, Rotterdam, the Netherlands
}

Background: Frail older people are at high risk of developing adverse outcomes, such as disability, mortality, hospitalization, and institutionalization. Previous research suggests that the Tilburg Frailty Indicator (TFI) is a valid and reliable instrument for measuring frailty. The aim of this study was to adapt and to test the reliability of the Polish version of the TFI.

Method: A standard guideline was used for translation and cultural adaptation of the English version of the TFI into Polish. The study included 100 Polish patients (mean age 68.2 \pm 6.5 years), among them 42 men and 58 women. Cronbach's alpha was used for analysis of the internal consistency of the TFI.

Results: The mean total TFI score was $6.7 \pm 3.1$. Forty patients scored $\geq 5$, which corresponded to being frail. Cronbach's alpha reliability coefficients of the instrument ranged from 0.68 to 0.72 and item-total correlation ranged from 0.12 to 0.52 .

Conclusion: The TFI is valid and reproducible for assessment of frailty syndrome among a Polish population. The Polish adaptation of the TFI proved a useful and fast tool for assessing frailty.

Keywords: internal consistency, validity, older individuals, aging

\section{Introduction}

The population of Western countries is aging. In Europe, the number of older people is expected to almost double in the next decade. According to the European Commission, the number of older people in Europe is estimated to triple by $2060 .{ }^{1}$

Frailty constitutes a new concept in geriatric research and practice. Over the last decades, there has been a significant rise in the use of the term "frailty" in the literature. ${ }^{2}$ Frail older people are at high risk of developing adverse outcomes, such as disability, mortality, hospitalization, and institutionalization. ${ }^{3}$ Current literature on frailty supports the notion of a pathway to disability that is not a direct result of chronic disease but is associated with age-related loss of physical condition and reserves. ${ }^{4}$

There is an ongoing debate about the definition of frailty. ${ }^{5}$ There is agreement on the core feature of frailty: an increased vulnerability to stressors caused by impairments in multiple interrelated systems that leads to a decline in homeostatic reserve and resiliency. ${ }^{6}$ Despite a lack of consensus on the definition of frailty, there seems to be agreement on the clinical usefulness of the concept. ${ }^{6}$ Whatever the inclusion criteria or the population affected, various studies report on the increased risk of complications for those identified as susceptible to adverse effects. ${ }^{7}$ Although everybody is vulnerable to a certain degree, it is reaching old age that involves greater risks of exposure to challenges and, crucially, of reduced capacity to respond to these exposures. ${ }^{8}$

The concept of frailty is believed to help clinicians and researchers understand the heterogeneity and inequalities of health trajectories of aging and to offer practitioners
Correspondence: Izabella Uchmanowicz Department of Clinical Nursing Wrocław Medical University, ul Bartla 5, 5I-618Wrocław, Poland $\mathrm{Tel}+487 \mid 784$ I824

Fax +48713459324

Email izabella.uchmanowicz@umed.wroc.pl 
useful tools for patient care. ${ }^{9}$ No instrument that addresses a multidimensional concept of frailty has been identified in Polish literature.

Most instruments, eg, the Phenotype of Frailty and the Frailty Scale, ${ }^{3,4}$ assess only physical frailty, whereas the Tilburg Frailty Indicator (TFI) also assesses psychological and social frailty. ${ }^{10}$ The TFI is based on the definition of frailty as a dynamic state affecting an individual who experiences losses in one or more domains of human functioning (physical, psychological, or social), which are caused by the influence of a range of variables and which increase the risk of adverse outcomes. ${ }^{11}$ Previous research suggests that the TFI is a valid and reliable instrument for measuring frailty. ${ }^{12}$ Gobbens et al ${ }^{13}$ have reported strong associations between TFI scores and quality of life, disability, and the use of nursing and informal care. The predictive value of the TFI regarding disability and hospitalization was confirmed in a 1 -year prospective study. The odds ratios for developing disabilities or being admitted to a hospital among persons older than 70 years, who were identified as frail using the TFI, equaled at least 2 , and the sensitivity of the instrument exceeded $60 \%$ for both outcomes. ${ }^{14}$ Moreover, the authors of one recently published systematic review identified the TFI as one of several potentially suitable screening instruments for frailty in primary health care. ${ }^{15}$ As reported in 2013, a consensus group on frailty agreed that the TFI is a well-validated model of the concept. ${ }^{16}$ Therefore, we have chosen the TFI for Polish translation and adaptation because it has met certain requirements, such as satisfactory validation and psychometric properties in its original culture. ${ }^{13}$

The aim of this study was to adapt and to test the reliability of the Polish version of the TFI, an instrument used to determine levels of frailty.

\section{Materials and methods}

\section{Study design}

The study was carried out in community-based settings in Wrocław, Poland. Data were collected from May 1, 2013 through August 31, 2013. Nurses and doctors administered the TFI in primary care facilities in Wrocław. All patients gave their written informed consent for participation in the study. Inclusion criteria were age $\geq 60$ years and a written informed consent to participate in this study. The only exclusion criteria were communication barriers (eg, deafness or blindness) or problems with manual dexterity. The protocol for the study was approved by the Local Bioethical Committee of Wrocław Medical University (decision Nbr460/2013).

\section{Instrument}

TFI consists of two different parts. One addresses sociodemographic characteristics of a participant (sex, age, marital status, country of origin, educational level, and monthly income) and potential determinants of frailty. The second part addresses components of frailty. Part two of the TFI comprises 15 selfreported questions, divided into three domains. The physical domain (0-8 points) consists of eight questions related to physical health, unexplained weight loss, difficulty in walking, balance, hearing problems, vision problems, strength in hands, and physical tiredness. The psychological domain ( $0-4$ points) comprises four items related to cognition, depressive symptoms, anxiety, and coping. The social domain (0-3 points) comprises three questions related to living alone, social relations, and social support. Eleven items of part two of the TFI have two response categories ("yes" and "no"), while the other items have three ("yes", "no," and "sometimes"). "Yes" or "sometimes" responses are scored 1 point each, while "no" responses are scored 0 . The instrument's total score may range from 0 to 15: the higher the score, the higher one's frailty. Frailty is diagnosed when the total TFI score is $\geq 5 .{ }^{13}$

\section{Translation process}

A standard guideline was used for translation and cultural adaptation of the English version of the TFI into Polish. ${ }^{17}$ After obtaining permission from the authors of the original instrument, it was independently translated into Polish by two translators specializing in biomedical projects. Subsequently, both translations were assessed by a panel of ten competent referees for the form and content of individual statements and for appropriateness and clarity of the questionnaire's instructions. The panel consisted of five geriatric and cardiovascular nurses, two physicians (one gerontologist and one cardiologist), and three specialists in health psychology. Each panel member had over ten years of experience working with frailty patients. Eventually, when the referees reached consensus on the final version of the translation, it was subjected to a back-translation process and sent to the authors of the original instrument for their approval. Subsequently, the preliminary adaptation was subjected to a preliminary study in a group of 30 randomly chosen patients. Eventually, the final Polish version of the TFI was obtained and analyzed according to the study design. The results are reported below.

\section{Participants}

The study included 100 consecutive Polish patients (mean age, $68.2 \pm 6.5$ years; median age, 67 years, interquartile range, 64-71 years), among them 42 men and 58 women. 
All of the participants agreed to participate in the project and answered all questions included in the adaptation of the TFI. The majority of our participants were married $(n=57)$ and had secondary education $(n=51)$. As many as 65 of the subjects suffered from at least two chronic disorders.

We decided to include 100 patients in our analysis as, according to the literature, the minimum sample size should be at least five times larger than the number of variables being analyzed (the number of TFI items is 15 , so the minimum sample size should be 75). ${ }^{18}$

\section{Statistical analysis}

Statistical analysis was conducted using the Statistica 10 package (StatSoft, Tulsa, OK, USA). The normal distribution of continuous variables was verified with the Kolmogorov-Smirnov test, and their statistical characteristics were expressed as arithmetic means \pm standard deviations, medians, interquartile ranges, and ranges. Categorical variables were expressed as absolute frequencies (n).
Cronbach's alpha, as a measure of the correlations between different items on the Polish adaptation of the TFI scale, was used to evaluate the internal consistency of the TFI. According to some authors, values of Cronbach's alpha are considered optimal at $\geq 90$, good at $\geq 0.80$, acceptable at $\geq 0.70$, questionable at $\geq 0.60$, poor at $\geq 0.50$, and unacceptable at $<0.50 .{ }^{19}$ However some researchers, especially from the field of social sciences, have suggested that instruments with internal consistency scores of at least 0.60 should not be discounted as long as the results are interpreted cautiously and within the whole sociodemographic context. ${ }^{20}$ Similar to a previous validation study, ${ }^{21}$ only the second part, ie, the part used to determine the level of frailty, was tested for its internal consistency.

\section{Results}

The statistical characteristics of the total TFI score and the scores of individual domains are presented in Table 1. The mean total score was $6.7 \pm 3.1$. Forty patients scored $\geq 5$.

Table I Statistical characteristics of the total TFI score and the scores of individual domains and items

\begin{tabular}{|c|c|c|c|c|c|}
\hline Variable & Mean \pm SD & Median & IQR & Range & $\mathbf{N} \max$ \\
\hline Physical domain & $3.7 \pm 1.9$ & 4.0 & $2.5-5.0$ & $0-8$ & 2 \\
\hline $\begin{array}{l}\text { I. Czy czujesz się zdrowy fizycznie? } \\
\text { (Do you feel physically healthy?) }\end{array}$ & $0.6 \pm 0.5$ & 1.0 & $0.0-1.0$ & $0-1$ & 64 \\
\hline $\begin{array}{l}\text { 2. Czy ostatnio straciłeś sporo na wadze, mimo że nie chciałeś? } \\
\text { (Have you lost a lot of weight recently without wishing to do so?) }\end{array}$ & $0.1 \pm 0.3$ & 0.0 & $0.0-0.0$ & $0-1$ & 14 \\
\hline $\begin{array}{l}\text { 3. Czy na co dzień doświadczasz trudności z powodu trudności w chodzeniu? } \\
\text { (Do you experience problems in your daily life due to difficulty in walking?) }\end{array}$ & $0.3 \pm 0.5$ & 0.0 & $0.0-1.0$ & $0-1$ & 34 \\
\hline $\begin{array}{l}\text { 4. Czy na co dzień doświadczasz trudności z powodu trudności w utrzymaniu równowagi? } \\
\text { (Do you experience problems in your daily life due to difficulty maintaining your balance?) }\end{array}$ & $0.3 \pm 0.5$ & 0.0 & $0.0-1.0$ & $0-1$ & 31 \\
\hline $\begin{array}{l}\text { 5. Czy na co dzień doświadczasz trudności z powodu słabego słuchu? } \\
\text { (Do you experience problems in your daily life due to poor hearing?) }\end{array}$ & $0.5 \pm 0.5$ & 1.0 & $0.0-1.0$ & $0-1$ & 51 \\
\hline $\begin{array}{l}\text { 6. Czy na co dzień doświadczasz trudności z powodu słabego wzroku? } \\
\text { (Do you experience problems in your daily life due to poor vision?) }\end{array}$ & $0.7 \pm 0.5$ & 1.0 & $0.0-1.0$ & $0-1$ & 72 \\
\hline $\begin{array}{l}\text { 7. Czy na co dzień doświadczasz trudności z powodu braku siły w dłoniach? } \\
\text { (Do you experience problems in your daily life due to lack of strength in your hands?) }\end{array}$ & $0.3 \pm 0.5$ & 0.0 & $0.0-1.0$ & $0-1$ & 29 \\
\hline $\begin{array}{l}\text { 8. Czy na co dzień doświadczasz trudności z powodu fizycznego zmęczenia? } \\
\text { (Do you experience problems in your daily life due to physical tiredness?) }\end{array}$ & $0.7 \pm 0.4$ & 1.0 & $0.5-1.0$ & $0-1$ & 75 \\
\hline Psychological domain & $1.7 \pm 1.2$ & 2.0 & $1.0-3.0$ & $0-4$ & 8 \\
\hline 9. Czy masz problemy z pamięciq? (Do you have problems with your memory?) & $0.2 \pm 0.4$ & 0.0 & $0.0-0.0$ & $0-1$ & 22 \\
\hline $\begin{array}{l}\text { 10. Czy zdarzało Ci się odczuwać obniżenie nastroju na przestrzeni ostatniego miesiqca? } \\
\text { (Have you felt down during the last month?) }\end{array}$ & $0.3 \pm 0.5$ & 0.0 & $0.0-1.0$ & $0-1$ & 32 \\
\hline $\begin{array}{l}\text { II. Czy odczuwałeś zdenerwowanie lub podniecenie na przestrzeni ostatniego miesiqca? } \\
\text { (Have you felt nervous or anxious during the last month?) }\end{array}$ & $0.8 \pm 0.4$ & 1.0 & $1.0-1.0$ & $0-1$ & 77 \\
\hline $\begin{array}{l}\text { 12. Czy umiesz sobie dobrze radzić z problemami? } \\
\text { (Are you able to cope with problems well?) }\end{array}$ & $0.4 \pm 0.5$ & 0.0 & $0.0-1.0$ & $0-1$ & 40 \\
\hline Social domain & $1.2 \pm 1.0$ & 1.0 & $0.0-2.0$ & $0-3$ & 16 \\
\hline 13. Czy mieszkasz sam? (Do you live alone?) & $0.3 \pm 0.5$ & 0.0 & $0.0-1.0$ & $0-1$ & 31 \\
\hline $\begin{array}{l}\text { 14. Czy zdarza Ci się tęsknić za towarzystwem innych osób? } \\
\text { (Do you sometimes miss having people around you?) }\end{array}$ & $0.6 \pm 0.5$ & 1.0 & $0.0-1.0$ & $0-1$ & 62 \\
\hline $\begin{array}{l}\text { 15. Czy otrzymujesz wystarczajqco dużo wsparcia od innych? } \\
\text { (Do you receive enough support from other people?) }\end{array}$ & $0.3 \pm 0.5$ & 0.0 & $0.0-1.0$ & $0-1$ & 32 \\
\hline Total score & $6.7 \pm 3.1$ & 6.5 & $4.5-9.0$ & $0-14$ & 2 \\
\hline
\end{tabular}

Abbreviations: TFI, Tilburg Frailty Indicator; SD, standard deviation; IQR, interquartile range; $N$ max, number of respondents with the highest possible score. 
Table 2 The analysis of the reliability of the Polish version of the Tilburg Frailty Indicator (the original and adapted versions)

\begin{tabular}{|c|c|c|}
\hline Variable & $\begin{array}{l}\text { Corrected item-total } \\
\text { correlation }\end{array}$ & $\begin{array}{l}\text { Cronbach's alpha } \\
\text { if item deleted }\end{array}$ \\
\hline \multicolumn{3}{|l|}{ Physical domain } \\
\hline $\begin{array}{l}\text { I. Czy czujesz się zdrowy fizycznie? } \\
\text { (Do you feel physically healthy?) }\end{array}$ & 0.48 & 0.69 \\
\hline $\begin{array}{l}\text { 2. Czy ostatnio straciłeś sporo na wadze, mimo że nie chciałeś? } \\
\text { (Have you lost a lot of weight recently without wishing to do so?) }\end{array}$ & 0.12 & 0.72 \\
\hline $\begin{array}{l}\text { 3. Czy na co dzień doświadczasz trudności z powodu trudności w chodzeniu? } \\
\text { (Do you experience problems in your daily life due to difficulty in walking?) }\end{array}$ & 0.41 & 0.70 \\
\hline $\begin{array}{l}\text { 4. Czy na co dzień doświadczasz trudności z powodu trudności w utrzymaniu równowagi? } \\
\text { (Do you experience problems in your daily life due to difficulty maintaining your balance?) }\end{array}$ & 0.35 & 0.70 \\
\hline $\begin{array}{l}\text { 5. Czy na co dzień doświadczasz trudności z powodu słabego słuchu? } \\
\text { (Do you experience problems in your daily life due to poor hearing?) }\end{array}$ & 0.34 & 0.71 \\
\hline $\begin{array}{l}\text { 6. Czy na co dzień doświadczasz trudności z powodu słabego wzroku? } \\
\text { (Do you experience problems in your daily life due to poor vision?) }\end{array}$ & 0.16 & 0.72 \\
\hline $\begin{array}{l}\text { 7. Czy na co dzień doświadczasz trudności z powodu braku sily w dłoniach? } \\
\text { (Do you experience problems in your daily life due to lack of strength in your hands?) }\end{array}$ & 0.37 & 0.70 \\
\hline $\begin{array}{l}\text { 8. Czy na co dzień doświadczasz trudności z powodu fizycznego zmęczenia? } \\
\text { (Do you experience problems in your daily life due to physical tiredness?) }\end{array}$ & 0.30 & 0.71 \\
\hline \multicolumn{3}{|l|}{ Psychological domain } \\
\hline $\begin{array}{l}\text { 9. Czy masz problemy z pamięciq? } \\
\text { (Do you have problems with your memory?) }\end{array}$ & 0.47 & 0.69 \\
\hline $\begin{array}{l}\text { 10. Czy zdarzało Ci się odczuwać obniżenie nastroju na przestrzeni ostatniego miesiqca? } \\
\text { (Have you felt down during the last month?) }\end{array}$ & 0.38 & 0.70 \\
\hline $\begin{array}{l}\text { II. Czy odczuwałeś zdenerwowanie lub podniecenie na przestrzeni ostatniego miesiqca? } \\
\text { (Have you felt nervous or anxious during the last month?) }\end{array}$ & 0.14 & 0.73 \\
\hline $\begin{array}{l}\text { 12. Czy umiesz sobie dobrze radzić z problemami? } \\
\text { (Are you able to cope with problems well?) }\end{array}$ & 0.52 & 0.68 \\
\hline \multicolumn{3}{|l|}{ Social domain } \\
\hline $\begin{array}{l}\text { 13. Czy mieszkasz sam? } \\
\text { (Do you live alone?) }\end{array}$ & 0.25 & 0.71 \\
\hline $\begin{array}{l}\text { 14. Czy zdarza Ci się tęsknić za towarzystwem innych osób? } \\
\text { (Do you sometimes miss having people around you?) }\end{array}$ & 0.20 & 0.72 \\
\hline $\begin{array}{l}\text { 15. Czy otrzymujesz wystarczajqco dużo wsparcia od innych? } \\
\text { (Do you receive enough support from other people?) }\end{array}$ & 0.32 & 0.71 \\
\hline
\end{tabular}

Note: Cronbach's alpha $=0.72$.

Cronbach's alpha reliability coefficients ranged from 0.68 to 0.72 after deletion of each item. The coefficients for total and item-total correlation, and after deletion of each item, are shown in Table 2.

\section{Discussion}

The purpose of this study was to adapt and test the reliability of a Polish version of the TFI. The instrument is based on the definition of frailty as a dynamic state affecting an individual who experiences losses in one or more domains of human functioning (physical, psychological, social), which are caused by the influence of a range of variables and which increase the risk of adverse effects. ${ }^{11}$ Previous research suggests that the TFI is a valid and reliable instrument for measuring frailty. The TFI is also efficient: completion of the TFI takes less than 15 minutes and does not require faceto-face contact. ${ }^{12}$
The TFI proved a valid measure of frailty in our reference sample. The instrument was characterized by good construct validity, reliability, and acceptable internal consistency. The internal consistency of the adapted version of the scale was determined by means of Cronbach's alpha. In a group of 100 patients, Cronbach's alpha was 0.72 . This value is similar to that documented in the case of the original Dutch version of the TFI $(0.79)^{13}$ and its Brazilian adaptation (0.78). ${ }^{21}$

According to the literature, up to $40 \%$ of older people can be considered frail. ${ }^{22}$ This statement would be supported by the results presented here, since as many as $40 \%$ of our participants were identified as frail on the basis of TFI scores $\geq 5$. Also the proportion of frail individuals documented in the abovementioned Brazilian validation study of the TFI was well above $30 \% .{ }^{21}$ However, one should remember that our sample was likely not representative of a general population of older people because only the 
subjects who had been referred to a general practitioner were examined. Furthermore, we have excluded individuals who suffered from any communication barriers. Thus, the true prevalence of frailty can be either lower or higher and should not be determined on the basis of a validation study.

The results of the present study should be interpreted in the context of potential limitations. Firstly, we were unable to assess the test-retest reliability or the construct and predictive validity of the instrument. Therefore, our results indicate, but do not prove, that the translated version of the TFI is a reliable measure of a common trait (likely frailty). Secondly, despite the widespread use of Cronbach's alpha to evaluate internal consistency in physiological research, the value of this test raises a number of concerns..$^{23}$ Thirdly, one cannot guarantee that the selection of our participants was completely random. Finally, we did not test validated measures of the frailty domains (eg, Timed Up and Go, grip strength, and Mini Mental State Examination) in our group. Future studies could analyze the predictive value of the TFI with respect to disability, health service utilization, and mortality.

\section{Conclusion}

Our study revealed that the instrument tested herein is valid and reproducible for assessment of the frailty syndrome among a Polish population. The Polish adaptation of the TFI proved a useful and fast tool for assessing frailty.

\section{Disclosure}

The authors report no conflicts of interest in this work.

\section{References}

1. Directorate-General for Economic and Financial Affairs of the European Commission. The 2009 Ageing Report: Economic and Budgetary Projections for the EU-27 Member States (2008-2060). European Economy 2; 2009. Available from: http://ec.europa.eu/economy_finance/publications/ publication14992_en.pdf. Accessed May 23, 2014.

2. Hogan DB, MacKnight C, Bergman H; Steering Committee, Canadian Initiative on Frailty and Aging. Models, definitions, and criteria of frailty. Aging Clin Exp Res. 2003;15(3 suppl):1-29.

3. Fried LP, Tangen CM, Walston J, et al. Frailty in older adults: evidence for a phenotype. J Gerontol A Biol Sci Med Sci. 2001;56:M146-M156.

4. Hallberg IR, Kristensson J. Preventive home care of frail older people: a review of recent case management studies. J Clin Nurs. 2004;13: $112-120$.

Clinical Interventions in Aging

\section{Publish your work in this journal}

Clinical Interventions in Aging is an international, peer-reviewed journal focusing on evidence-based reports on the value or lack thereof of treatments intended to prevent or delay the onset of maladaptive correlates of aging in human beings. This journal is indexed on PubMed Central, MedLine,
5. Abellan van Kan G, Rolland Y, Houles M, Gillette-Guyonnet S, Soto M, Vellas B. The assessment of frailty in older adults. Clin Geriatr Med. 2010;26:275-286.

6. Bergman H, Ferrucci L, Guralnik J, et al. Frailty: an emerging research and clinical paradigm-issues and controversies. J Gerontol A Biol Sci Med Sci. 2007;62:731-737.

7. Aminzadeh F, Dalziel WB, Molnar FJ. Targeting frail older adults for outpatient comprehensive geriatric assessment and management services: an overview of concepts and criteria. Rev Clin Gerontol. 2002; $12: 82-92$

8. Fox-Wasylyshyn SM, El-Masri MM. Handling missing data in selfreport measures. Res Nurs Health. 2005;28(6):488-495.

9. De Lepeleire J, Degryse J, Illiffe S, Mann E, Buntinx F. Family physicians need easy instruments for frailty. Age Ageing. 2008;37(4):484.

10. Grundy E. Ageing and vulnerable elderly people: European perspectives. Ageing and Society. 2006;26:105-134.

11. Gobbens RJ, Luijkx KG, Wijnen-Sponselee MT, Schols JM. Toward a conceptual definition of frail community dwelling older people. Nurs Outlook. 2010;58:76-86.

12. Gobbens RJ, van Assen MA, Luijkx KG, Schols JM. The predictive validity of the Tilburg Frailty Indicator: disability, health care utilization, and quality of life in a population at risk. Gerontologist. 2012;52: 619-631.

13. Gobbens RJ, van Assen MA, Luijkx KG, Wijnen-Sponselee MT, Schols JM. The Tilburg Frailty Indicator: psychometric properties. J Am Med Dir Assoc. 2010;11:344-355.

14. Daniels R, van Rossum E, Beurskens A, van den Heuvel W, de Witte L. The predictive validity of three self-report screening instruments for identifying frail older people in the community. BMC Public Health. 2012;12:69.

15. Pialoux T, Goyard J, Lesourd B. Screening tools for frailty in primary health care: a systematic review. Geriatr Gerontol Int. 2012;12: 189-197.

16. Morley JE, Vellas B, van Kan GA, et al. Frailty consensus: a call to action. J Am Med Dir Assoc. 2013;14(6):392-397.

17. Brislin RW. Back-translation for cross-cultural research. J CrossCultural Psychol. 1970;1:185-216.

18. Hair J, Anderson R, Tatham R, Black W. [Factorial analysis]. In: Hair J, Anderson R, Tatham R, Black W, editors. Analise Mutivariada de Dados. Porto Alegre (RS): Bookman; 2005:89-127. Italian.

19. Beaton D, Bombardier C, Guillemin F, Ferraz M. Recommendations for the Cross-Cultural Adaptation of the DASH and Quick DASH Outcome Measures. Toronto: Institute for Work and Health; 2007.

20. Gliem J, Gliem R. Calculating, interpreting, and reporting Cronbach's alpha reliability coefficient for Likert-type scales. Paper presented at: Midwest Research-to-Practice Conference in Adult, Continuing, and Community Education; October 8-10, 2003; Columbus, OH.

21. Santiago LM, Luz LL, Mattos IE, Gobbens RJ, van Assen MA. Psychometric properties of the Brazilian version of the Tilburg frailty indicator (TFI). Arch Gerontol Geriatr. 2013;57(1):39-45.

22. Slaets JP. Vulnerability in the elderly: frailty. Med Clin North Am. 2006; 90:593-601.

23. Dunn TJ, Baguley T, Brunsden V. From alpha to omega: A practical solution to the pervasive problem of internal consistency estimation. Br J Psychol. Epub 2013 Aug 6. 